\title{
GI school projects and their value and transferability to Uzbekistan
}

\author{
Sabine Hennig, ${ }^{1, *}$, and Robert Vogler ${ }^{2}$ \\ ${ }^{1}$ University of Salzburg, Department of Geoinformatics, 5020 Salzburg, Austria \\ ${ }^{2}$ University of Salzburg, Department of Geography and Geology, 5020 Salzburg, Austria
}

\begin{abstract}
Geospatial technologies and spatial data have increasingly become a key issue in our world with regard to digitalization. The ability and capability to handle spatial data products is a key competence in the 21 st century. Accordingly, school education is an important domain to address these skills, but still lacks behind its actual potential - even if numerous concepts and approaches already exist. A promising means of addressing this issue is to actively involve schools in real-world GI projects. This paper sums up relevant educational approaches and concepts that are important for such initiatives and briefly describes four selected projects that were carried out in Austria. Based on the knowledge gained in these projects, challenges and benefits are presented, and the transferability and the potential of carrying out such projects in Uzbekistan is discussed.
\end{abstract}

\section{Introduction and research questions}

With the digitalization in all areas of living, including work and private life, the use of Information and Communication Technologies (ICT) has become a key issue for everyone everywhere on earth. This was compounded by the Covid-19 pandemic [1]. Digital communication and interaction processes in real time based on web 2.0 and mobile technologies are an essential part of our everyday life [2]. This also includes the use of geospatial technologies and data. Online maps, for example, which are omnipresent on the internet today, are an excellent example of the role geospatial technologies and data play for everybody [3]. They help people to orient themselves in physical space, navigate from place to place, plan routes, acquire spatial knowledge, build up cognitive or mental maps, share spatial information, organize information, and participate in different types of public participation initiatives that increasingly integrate geospatial technologies [4-6]. Now, the competent and capable use of spatial products including online maps requires spatial literacy skills on the part of the users. In the literature, some specific skills are emphasized that are important for this. These skills include digital skills as well as the capabilities to handle spatial data and spatial data products [7]. Table 1 gives an overview of these skills.

\footnotetext{
* Corresponding author: $\underline{\text { sabine.hennig@sbg.ac.at }}$
} 
Table 1. Overview of spatial literacy skills including general digital skills and spatial representation handling skills [based on 7]

\begin{tabular}{|c|c|c|c|}
\hline \multirow[t]{2}{*}{ Digital skills } & \multicolumn{3}{|c|}{ Spatial representations handling skills } \\
\hline & $\begin{array}{l}\text { Map reading/ one } \\
\text { way communication }\end{array}$ & $\begin{array}{l}\text { Map making/ } \\
\text { two way com- } \\
\text { munication }\end{array}$ & $\begin{array}{l}\text { Basic GI and car- } \\
\text { tography related } \\
\text { concepts and terms }\end{array}$ \\
\hline $\begin{array}{l}\text { - Using a digital medium } \\
\text { in general } \\
\text { - Handling the formal } \\
\text { structures of the medi- } \\
\text { um (e.g., browsing, } \\
\text { navigation) } \\
\text { - Searching, selecting, } \\
\text { evaluating information } \\
\text { in digital media } \\
\text { - Mailing, contacting, } \\
\text { creating online identi- } \\
\text { ties, draw attention, } \\
\text { giving opinions } \\
\text { Making contributions } \\
\text { with a plan, design; } \\
\text { taking data privacy, in- } \\
\text { tellectual property } \\
\text { rights IIPR) into ac- } \\
\text { count } \\
\text { - Using the digital medi- } \\
\text { um as a means to } \\
\text { achieve particular pro- } \\
\text { fessional and personal } \\
\text { goals }\end{array}$ & $\begin{array}{l}\text { - Using online maps: } \\
\text { e.g., find and open } \\
\text { tools, orient and } \\
\text { navigate on the } \\
\text { map (e.g. zoom, } \\
\text { pan), find places } \\
\text { switch basemaps, } \\
\text { turn layers on/ off, } \\
\text { measure) } \\
\text { - Accessing/ retriev- } \\
\text { ing information } \\
\text { (e.g., available in } \\
\text { feature pop-ups) } \\
\text { - Output (e.g., print, } \\
\text { save, share) } \\
\text { - Etc. }\end{array}$ & $\begin{array}{l}\text { - Creating maps, } \\
\text { adding features } \\
\text { (i.e., markers, } \\
\text { lines, areas) } \\
\text { - Adding and } \\
\text { combining in- } \\
\text { formation (e.g., } \\
\text { by pop-ups) } \\
\text { - Handling spa- } \\
\text { tial data (i.e., } \\
\text { import, export, } \\
\text { convert, trans- } \\
\text { fer) } \\
\text { - Re-using spa- } \\
\text { tial data (find, } \\
\text { assess, inte- } \\
\text { grate) } \\
\text { Etc. }\end{array}$ & $\begin{array}{l}\text { - Knowing/ under- } \\
\text { standing relevant } \\
\text { technical terms } \\
\text { (e.g., pan, layer, } \\
\text { basemap) } \\
\text { - Being aware of } \\
\text { cartographic design } \\
\text { guidelines (e.g., de- } \\
\text { cide upon adequate } \\
\text { symbols, basemaps, } \\
\text { use/ integrate mul- } \\
\text { timedia) } \\
\text { - Critical reflection } \\
\text { on the power of } \\
\text { maps; use of maps } \\
\text { as a powerful me- } \\
\text { diator of particular } \\
\text { interests } \\
\text { - Etc. }\end{array}$ \\
\hline
\end{tabular}

In society, however, people not only have different levels of skills to use ICT $[8,9]$, but also to handle geospatial technologies $[10,11]$. This is where formal school education can play a key role in building these skills in society. Especially secondary education has become a fundamental domain for geomedia education approaches and concepts [12]. Here, the inclusion of spatial data (products) has already taken place to a certain extent [e.g., 13, 14]. Nevertheless, we are (still) faced with the challenge that many teachers still lack spatial literacy skills [15], and that this topic cannot be/ is not assigned to a single school subject. A promising means of addressing these issues is to include schools in projects that focus on the use of geospatial technologies and data (GI projects) and that require public involvement. In addition to public participation, citizen science, crowd mapping, and non-profit sharing economy initiatives, this refers to research projects aiming at developing usercentered products, learning about ICT and GI laypeople and raising people's awareness of topics related to the use of ICT and GI. The added value of this approach for schools is underpinned by the numerous benefits that refer, among other things, to project-based learning such as increased motivation and sustainability of learning [16].

In developed countries (e.g. the EU) such initiatives have gained increasing interest in recent years (see, e.g., conferences such as Learning by Geoinformation, GI_Forum). With regard to developing countries, there are fewer examples such as such run by the Humanitarian OpenStreetMap Team [see, e.g., 17]. But, what additional benefits does cooperating in GI projects bring for schooling and school students - apart from benefits related to project-based learning? If we distinguish between developed and developing 
countries, what are the benefits for developing countries and does it make sense to apply this approach in those countries?

Based on a selection of GI projects that took place in Austria in which the cooperation with schools and school students was a key aspect; these questions are discussed in this paper. Section 2 presents approaches and educational concepts that are of relevance for such cooperations. Based on the experience from four projects (section 3), selected challenges and benefits of such cooperation are discussed in section 4 and 5 . The value of such projects for developing countries is highlighted using the example of Uzbekistan (section 6). A conclusion and outlook is given in section 7.

\section{Approaches and concepts}

In recent years, a wide range of approaches using geoinformation technologies in education emerged. Of particular importance for the cooperation of schools in GI projects are (i) science education, (ii) the spatial citizenship concept, and (iii) the general support of learning processes by spatial contextualization with geomedia (learning) environments (e.g., the SELTAS approach). These concepts are briefly described below.

\subsection{Science education}

Many approaches regarding the use of geoinformation in education stem from the science education domain. These concepts aim to foster spatial thinking on one hand and (technology-driven) analytical thinking on the other. One of the most prominent initiatives in this field is the "Learning to think spatially" concept: "The key to spatial thinking is a constructive amalgam of three elements: concepts of space, tools of representation, and processes of reasoning. It is the concept of space that makes spatial thinking a distinctive form of thinking" [18: 12]. In this context, spatial thinking, analytical thinking and technology-supported digital (geo)visualization abilities are considered as key competences in the $21^{\text {st }}$ century, which can be fostered by an active integration of geoinformation technologies in the classroom [19].

\subsection{Spatial Citizenship}

On the contrary, the spatial citizenship approach [14] aims at the ability to interact and participate in societal negotiation processes with the support of geomedia. Based on a fundament of critical cartography [20], critical GIScience [21, 22], and a constructivist understanding of space and spatial meaning [23], it links geomedia usage with citizenship education aims. Theoretically, it is linked to an activist citizenship education approach [24] in combination with the emergence of online communities, networks and collaborations [25].

Based on the premise, that geomedia serve as powerful platform for the manifestation of spatial meaning, spatial citizenship focuses on two dimensions: (i) reflection and (ii) communication. Reflection refers to a mature appropriation of space and spatial meaning; and communication is linked to actively communicate own alternative meanings supported by geomedia. For this, spatial citizenship defines three competence fields, which are required to actively act as a spatial citizen: (i) technical and methodologic competences to handle spatial representations and geomedia, (ii) the competence to reflect, appraise and evaluate the use of spatial representations and geomedia, and (iii) the competence to actively communicate and participate with spatial representations and geomedia [14]. When these three competences are consistently fostered in (school) education, school students develop the ability and capability to participate in processes of spatial meaning production. 


\subsection{SELTAS}

Another approach focusing on geomedia and education is SELTAS (Spatially Enabled Learning and Teaching Across Subjects). In contrast to science education approaches and spatial citizenship, SELTAS is a concept that provides benefit to learning through spatial contextualization. Its main aim is the individual and collective generation and documentation of knowledge (including spatial analysis) in the framework of learning environments by adding a (geo)mediated spatial context to the leaning content [26, 27].

SELTAS uses the omnipresence of digital spatial information to support learning while taking into account the communicative and collaborative potential of the geoinformation society. Inspired by the variety of content, to which georeferences have been added in everyday life - from political issues to sustainable consumption to spatialized documentation of leisure activities - the focus lies on learning that uses spatial representations as added value for several subjects beyond purely geographical topics. Examples within this approach are learning about places mentioned in novels, about statistics concerning countries and regions, and about cartographic narrations on product chains. The approach is based on two main references:

i. relational spac, i.e., the idea of the attachment of meaning to mainly physical matter by communication through spatial representations [23] and a supportive spatial contextualization of content

ii. dual coding [28], i.e., the combination of pictorial (maps as picture) and symbolic elements (maps as text) that target different modes of information processing in the learners' reception, as described in mapping theory [29]

Based on the advantages of geomedia, SELTAS "[...] makes use of web-based spatial representations to support interaction, communication and document learning outcomes in educational contexts by connecting complex learning content to a spatial dimension. This can be achieved by contextualization, by cartographic support of arguments in communication processes or simply as a spatialized portfolio that may be either individual or collective or both" [26: 206].

\section{Exemplary projects}

Over the last couple of years, we carried out or took part in several projects in which we collaborated with schools such as (i) YouthMap5020, (ii) Fairtrade Oberndorf, (iii) the4bees, and (iv) citizenMorph. Even though their aims as well as methods and tools used differ widely, the common thread of all four projects was to address school students' geomedia skills in the context of specific settings: High school students contributed to each project in the context of several hours / days lasting workshops. Common to all projects is also that each one aimed at developing a product to which high school students have made a significant contribution. The four projects are briefly described in Table 2 and below.

Table 2: Overview of the projects

\begin{tabular}{|l|l|l|l|l|}
\hline Project & $\begin{array}{l}\text { Duration/ Fund- } \\
\text { ing }\end{array}$ & Key topic & Domains involved & Tools used \\
\hline $\begin{array}{l}\text { Youtmap- } \\
\mathbf{5 0 2 0}\end{array}$ & $\begin{array}{l}\text { 2013-2014 } \\
\text { National/ Austria: } \\
\text { FFG }\end{array}$ & $\begin{array}{l}\text { Youth-centred } \\
\text { city map }\end{array}$ & $\begin{array}{l}\text { Cartography, geog- } \\
\text { raphy, geoinformat- } \\
\text { ics, software devel- } \\
\text { opment }\end{array}$ & $\begin{array}{l}\text { ESRI's ArcGIS } \\
\text { Online }\end{array}$ \\
\hline $\begin{array}{l}\text { Fairtrade } \\
\text { Oberndorf }\end{array}$ & $\begin{array}{l}2015 \\
\text { National/ Austria: } \\
\text { FFG }\end{array}$ & $\begin{array}{l}\text { Sustainability, } \\
\text { responsible con- } \\
\text { sumption }\end{array}$ & $\begin{array}{l}\text { Cartography, geog- } \\
\text { raphy, geoinformat- } \\
\text { ics, economics }\end{array}$ & $\begin{array}{l}\text { ESRI's ArcGIS } \\
\text { Online }\end{array}$ \\
\hline
\end{tabular}




\begin{tabular}{|l|l|l|l|l|}
\hline the4bees & $\begin{array}{l}2015-2019 \\
\text { International/ } \\
\text { EU: } \\
\text { Interreg Alpine } \\
\text { Space }\end{array}$ & $\begin{array}{l}\text { Sustainable ener- } \\
\text { gy consumption }\end{array}$ & $\begin{array}{l}\text { Cartography, geoin- } \\
\text { formatics, sensing } \\
\text { technology }\end{array}$ & $\begin{array}{l}\text { ESRI's Story- } \\
\text { maps for ArcGIS } \\
\text { Online }\end{array}$ \\
\hline $\begin{array}{l}\text { citzen- } \\
\text { Morph }\end{array}$ & $\begin{array}{l}\text { National/ Austria: } \\
\text { FWF }\end{array}$ & $\begin{array}{l}\text { Geomorphologi- } \\
\text { cal features and } \\
\text { dynamics, climate } \\
\text { change }\end{array}$ & $\begin{array}{l}\text { Geomorphology/ } \\
\text { geograph, remote } \\
\text { sensing, geoinfor- } \\
\text { matics }\end{array}$ & $\begin{array}{l}\text { ESRIS's Survey } \\
123 \text { for ArcGIS } \\
\text { Online }\end{array}$ \\
\hline
\end{tabular}

\subsection{YouthMap}

The YouthMap 5020 project aimed at creating an online map for the city of Salzburg that is tailored to the needs of young people. The map was technically implemented as an ArcGIS online map application. Applying the approach of participatory design, about 120 high school students from several local schools were involved in all kinds of tasks related to the phases of generating the youth-centric Salzburg online city map. The decision to use the participatory design approach arose from the fact that literature highlights it as a strategy that is particularly useful when it comes to working with young people and when there is a need to directly and actively involve them in the development process. Following the participatory design approach, the YouthMap 5020 project team comprised adults as experts in geoinformatics and application development as well as young people as experts for their own requirements including, e.g., map content and design [11].

\subsection{FairTrade Oberndorf}

This project was a technical spin-off from the YouthMap5020 project. Since it developed its own dynamic, it will be mentioned here as an independent project. Despite the above-described, increasing (geo)digitalization of our world, this project showed that we are still faced with many challenges on the path towards an emancipatory geomedia usage by the general public. These challenges arise mainly from technical hurdles such as different data formats, data standards and systems, and their (at least partly) incompatibilities. To minimize these problems, within the project a workflow was developed that shows how to use a minimalistic and therefore universal technology structure for cross-platform work with spatial data, especially useful in school environments. The workflow development took place in the context of a school initiative, in which high school students created a dynamic and interactive online map application of their school town showing all retail stores where fair-trade products are available [30].

\section{3 the 4 bees}

The the 4 bees project aimed at an interactive teaching approach to give school students a better understanding of energy consumption by the implementation of real time sensors in their school building. It tackled the research question of how school students can get a clear and sustainable understanding about the topic of energy saving. To achieve this, students from three schools in the federal state of Salzburg were directly involved in research into energy saving. The school students participated in the entire research process from data collection to analysis and visualization of the results in digital story maps. Based on the related insights, teaching material and learning modules were designed for supra-regional/ international use [31]. 


\subsection{CitizenMorph}

The main objective of the citizenMorph project was to create a technological solution that allows and supports the general public to contribute data on landforms and geomorphological phenomena, the dynamic of which is actually steadily increasing due to the effects of climate change. The technological solution comprises a mobile app for mapping such landforms on-site as well as an extended internet presence consisting of a content management web site (providing all relevant information related to the topic and social networking capabilities) and different social media accounts. To provide a technological solution that is as tailored as possible to the citizens and their needs, representatives of the public (including high school students) were involved in its development in different ways. This included the specification of the citizen requirements as well as the design and implementation of prototypes which finally fed into the final product [32].

\section{Selected challenges}

Cooperating with young people is a challenging task per se. One of the reasons for this is that the youth is a fairly heterogeneous and complex user group. Regarding their ICT use, they can be described by the following aspects [33]: (i) overconfident of their computer and web abilities, (ii) reduced attention span, long reaction time, (iii) little patience, quick judgment, (iv) reluctances to read on screen and use manuals, (v) low willingness to explore implemented functionalities, and (vi) partly problems to get and keep an overview of complex tasks and workflows. In addition to these aspects, different challenges and problems with regard to working with students were identified in the context of the four projects. These are: lack of work routine and experience, lack of experience in participating in long-term tasks, age-related level of soft skills and technical skills.

This requires additional work and efforts that must be considered when cooperating with young people. Selected aspects identified in the course of the four projects are listed in Table 3. Moreover, conducting projects in cooperation with schools requires certain organization effort. Thus, for instance, to enable school students to participate in projectrelated workshops lasting several hours or days, teachers usually have to coordinate these activities in advance by clarifying with their school administration and other teachers, if their teaching time will be affected.

Table 3: Additional efforts (adapted from [32, 33])

\begin{tabular}{|l|l|}
\hline Categories & Description \\
\hline $\begin{array}{l}\text { Suitable } \\
\text { equipment }\end{array}$ & $\begin{array}{l}\text { - Hardware, devices, software applications and methods } \\
\text { - Mix of web-based and traditional methods } \\
\text { - Devices and tools preferred by young people (e.g., mobile devices/ phones) }\end{array}$ \\
\hline $\begin{array}{l}\text { Suitable } \\
\text { support }\end{array}$ & $\begin{array}{l}\text { - Providing an easy-to-understand big picture: overall project aim, workflow etc. } \\
\text { - Clearly structured and defined tasks, sticking to the agreed workflow } \\
\text { - Team composition: Support by peers to give appropriate explanations etc. } \\
\text { - Availability of comprehensive support: online and offline options } \\
\text { - Appropriate supportive material: technical terms, concepts, explanations etc. } \\
\text { - In-person meetings and roundups }\end{array}$ \\
\hline $\begin{array}{l}\text { Enough } \\
\text { scope for } \\
\text { development/ } \\
\text { time to work }\end{array}$ & $\begin{array}{l}\text { - Facing and handling long discussions that offer opportunities to present, } \\
\text { exchange and discuss ideas and gain recognition from others } \\
\text { being available for (online) discussions/ support out of company time etc. }\end{array}$ \\
\hline
\end{tabular}


- Expecting and dealing with school students' different knowledge and background

- Trusting in school students' skills

- Helping to carry responsibility

- Supporting decision making without bringing in your own ideas and opinions

- Helping young people to express themselves (reasoning, presentations)

- Involving school students in PR activities: school, family, other peers etc.

\section{Selected benefits}

On the contrary to these challenges, there are also numerous benefits. In addition to building spatial literacy skills, we have identified many of them in the context of the four projects. Some are highlighted and discussed below.

\subsection{Spatial literacy skills}

The projects presented have been proven to give school students the opportunity to build spatial literacy skills. This is related to the fact that in all projects school students contributed to the respective product development, which automatically contributed to the development of these skills. Thus, by actively and directly taking part in the various tasks, receiving explanations from the GI experts and/or working through tutorials and supportive material independently, they build these skills.

Here, our experiences are confirmed by the finding of other scholars. This relates, for instance, to De Luca et al. [34] or in another context Kerski [35] who emphasize that the use of spatial data and spatial data products in schools can foster spatial awareness and spatial literacy skills. An overview of the spatial literacy skills addressed by the four projects is given in Table 4.

Table 4: Spatial literacy skills addressed by the four projects

\begin{tabular}{|l|l|}
\hline Project & Spatial literacy skills (required/ build) \\
\hline Youthmap5020 & Map reading, mapping, map production \\
\hline Fairtrade Oberndorf & Map reading, mapping \\
\hline the4bees & Map reading, mapping, map production \\
\hline citizenMorph & Mapping \\
\hline
\end{tabular}

In addition, the school students' interest on spatial data products was aroused across all projects. This includes the relevance for everyday tasks as well as the availability of spatial data and tools (e.g., purposes, potential of crowdsourcing approaches). This corresponds to Sui et al. [36] who argue that such initiatives make it more likely that young people will use spatial data products for their private and school activities and later on in their working life. It also has the potential to spark students' interest in studying geoinformatics.

\subsection{Expanding horizons}

Cooperating with experts from different fields and working on real world topics in the context extracurricular activities showed the school students how important theory is for practical work and how different school subjects are intertwined and help tosolve problems and find solutions. It has helped to broaden their horizons on aspects that are generally not covered in school subjects as such. 
The projects YouthMap 5020 and the4bees - with a focus on software development and geoinformatics as well as more sustainable and reflective energy consumption behavioursensitized the school students in particular to STEM subjects (Science, Technology, Engineering, and Mathematics). The projects FairTrade Oberndorf and citizenMorph, which dealt with topics such as sustainability and social responsibility, addressed the improvement of school students' understanding of the relevance of public participation. Both are closely related to aspects such as citizenship responsibilities, which are considered as key educational issues - especially for the social challenges of the 21 st century [37]. Regarding all projects, the school students were impressed by the experience and knowledge they were able to gain, as well as the fact that they found interest in topics they previously considered uninteresting and boring. In terms of the YouthMap 5020 project, high school students explained they were surprised that software development is much more than just coding and how many different people from different backgrounds contribute to the development of software applications (e.g., media designer, sociologists, communication and PR experts).

Moreover, the fact of cooperating with experts (who serve as role models for the school students) and, in this context, the discussions with the experts about their work, the study and career opportunities behind it were seen as very useful and interesting by the young people. With regard to the citizenMorph project, for example, the interest of the school students was aroused in particular in topics such as geology and geomorphology. Further, by observing the experts, school students can modify their behavior/ attitude accordingly, as the behavioural change of students (in the context of energy consumption) throughout the 4 bees project showed [31]. This is in line with the approach of social learning.

\subsection{Soft skills}

Soft skills play an important role in school, studies and work. Here, activities like taking part in a project that focuses on collaboration and interaction, as well as being responsible for specific tasks, can help developing various soft skills. This refers to competencies related to teamwork, conflict management, communication and presentation tasks, and responsibility. Moreover, it required high school students to learn and work independently and self-paced and meet deadlines. Responsibility and independent work of the students were addressed by the fact that their personal interest was met by the project topics - which relate to their life and current situation and cover issues that are important to them (Table 2). Prüller et al. [38] also underline this: They highlight that taking local and/ or regional topics and data into account can motivate students to work self-driven and self-paced and to intensify their learning experience. This is also in line with the findings of situated learning approaches in general [39] and for science education in particular [40]. This is driven by the fact that personal relationships, consternation and interest in a topic are seen as key motivational factors for people to take part and get involved in whatever activity [41].

\subsection{Spatially enabled society and geo digital society}

Technological advances have triggered the development towards a society in which digital information and communication are key concepts, and in which actions are often supported - in some cases even replaced - by digital tools [42, 43]. Due to the advances and omnipresence of geospatial technologies, a spatially enabled society has emerged [44]. This means that almost everyone not only has spatial data products at his/her fingertips (e.g., geo portals, open government data), but should also have a certain level of spatial literacy skills to be able to use spatial data products in a competent and capable manner and, thus, benefit from spatial data. This relates to aspects such as becoming spatially informed, producing, 
publishing and sharing spatial data (e.g., user generated content, volunteered geographic information), and contributing to space-related questions such as citizen science or public participation projects. In this context, the spatially enabled society can also be understood as a geo-digital society [11]. Here, our projects contribute to building spatially enabled societies and geo digital societies in different ways. This refers, firstly, to building spatial literacy skills across the high school students. Secondly, it relates to getting teachers' interest in becoming (more) familiar with geospatial technologies and spatial data, and being prepared to include such aspects in their teaching activities [45]. Thirdly, school students, who were involved in cooperation with GI projects, can and will spread their knowledge and experience with geospatial technologies, products and data. As in the case of the YouthMap5020 and citizenMorph project this refers to their families but also friends. This is an important aspect, since for young people promotion through word of mouth and referrals is an important way to get informed [46].

\section{Transferability to Uzbekistan}

Several of the benefits outlined above are of interest for future educational GI projects in Uzbekistan. This Central Asian country is one of several republics from the former Soviet Union. A rough overview using some figures that are of particular interest in connection with this work is given in Table 5 .

Table 5: Key figures on Uzbekistan [47]

\begin{tabular}{|l|r|}
\hline Area $\left[\mathbf{k m}^{\mathbf{2}}\right]$ & 445711 \\
\hline Population (2018) & $32.96 \mathrm{Mio}$ \\
\hline School enrollment, secondary (\%) (2018) & 93 \\
\hline Mobile cellular subscriptions (per 100 people) (2018) & 71,5 \\
\hline Individuals using the Internet (\% of population) (2018) & 55,2 \\
\hline Net migration (thousands) (2018) & -44 \\
\hline
\end{tabular}

In Uzbekistan, the need for a sustainable economic development as well as to respond to climate change is affecting the country (e.g., changes in water distribution, natural hazards, loos of biodiversity) and creates a particular demand for GI experts [38, 48]. As emphasized by GPS [49:12), there is a substantial need to increase " $\ldots$ the number of youth and adults who have relevant skills, including technical and vocational skills, for employment, decent jobs and entrepreneurship ..." in the next few years thus ".... that all learners acquire the knowledge and skills needed to promote sustainable development". Considering this, schooling in Uzbekistan can greatly benefit from cooperating in GI projects. Hence, the aspects discussed in section 4 also apply to Uzbekistan, as this can increase the proportion of young people with ICT skills, including spatial literacy skills. Depending on the type and topic of the project, it also increases the extent to which global citizenship education and education for sustainable development are carried out - as requested by GPS [49].

Apart from this, there are additional benefits. For instance, with respect to soft skills, English language proficiency - which are often a problem in Central Asian countries [see e.g. 48], but a key issue in many areas - can be improved and interest in it can be aroused. Cooperating in GI projects, including using different (expert) tools, requires to become familiar with them. Since much of the supporting materials, including e-learning content, are usually available in English (e.g., video tutorials), school students will become aware of the importance of proficiency in English and will be motivated to learn English and improve their English skills. Thus, such projects can help to improve students' language skills in general [48]. 
Nevertheless, there are also some challenges particular for Uzbekistan regarding such teaching initiatives: For such projects, a good internet connectivity is substantially required. This is often a problem in Uzbekistan [50]. This can be countered by the fact that a large proportion of people around the world now own and use smartphones (incl. developing countries; Uzbek school students). This, along with high internet user penetration rates (i.e., mobile Internet) can free project managers from worrying too much about internet connectivity. In addition, allowing school students to use their mobile devices meets the preferences of this user group (i.e., digital natives) and, thus, can increase the acceptance of the project and the tasks they have to do.

The use of geospatial technologies is generally related to the use of substantial computer resources including software and spatial data $[38 ; 50]$. Here, free-of-charge software is suitable for such projects, as there are no or only minimal costs for licensing and great community-based support [38]. Moreover, for many chargeable software products special licenses for the education field, including schools, exist (e.g. ESRI campus program).

\section{Conclusion and outlook}

The cooperation of schools in GI projects is a useful means to build school students' spatial literacy skills. In addition, it brings some other benefits for young people (expanding their horizon, developing soft skills) as well as for society (development towards a spatially enabled society and geo digital society; citizenship responsibilities). Further, the link with school education also brings benefits for the GI projects: more publicity, awareness rising in society, projects will run smoother and faster, new insights etc. Nevertheless, cooperating with schools and school students is always challenging and requires additional work and effort. While, for instance, there are many examples of such initiative in EU states, the situation is still different in developing countries such as the Central Asian states. Through GI school projects, they can benefit from the opportunities described above.

To carry out such projects, opportunities such as those offered, e.g., by EU funding should be taken into consideration (for instance capacity building initiatives with regard to formal school education). This will promote interesting partnerships between institutions and organization in EU countries and Central Asian states, and bring many opportunities of exchange for school students.

\section{References}

1. European Commision, "Digital technologies - actions in response to coronavirus pandemic" [Online]. Available: https://ec.europa.eu/digital-singlemarket/en/content/digital-technologies-actions-response-coronavirus-pandemic [Accessed June 28 2020].

2. A. Darwish, K.I. Lakhtaria, The Impact of the New Web 2.0 Technologies in Communication, Development, and Revolutions of Societies, Journal of advances in information technology 2, 4, 204-216 (2011).

3. T. Thielmann, L. Van der Velden, F. Fischer, R. Vogler, Dwelling in the Web: Towards a Googlization of Space, HIIG Discussion Paper Series 2012, 03 (2011).

4. A.S. Helal, E. Moore, B. Ramachandran, Drishti: An Integrated Navigation System for Visually Impaired and Disabled, $2^{\text {nd }}$ IEEE Annual Conference on Pervasive Computing and Communications, Orlando, March 14-17 (2004).

5. D.R. Montello, S.M. Freundschuh, Cognition of Geographic Information (A Research Agenda for Geographic Information Science, edited by R. B. McMaster and E. L. Usery, 61-91. Boca Raton: CRC Press, 2005). 
6. J. Panek, From mental maps to geoparticipation, The Cartographic Journal 53, 4, 300307 (2016).

7. S. Hennig, S., R. Vogler, I. Gryl, Spatial Education for Different User Groups as a Prerequisite for Creating a Spatially Enabled Society and Leveraging SDI, International Journal of Spatial Data Infrastructre Research 8, 2013, 98-127 (2013) .

8. J. Nielsen, "Digital divide: the 3 stages" [Online]. Available: https://www.nngroup.com/articles/digital-divide-the-three-stages [Accessed Dec. 5 2019].

9. J. Van Dijk, The evolution of the digital divide - the digital divide turns to inequality of skills and usage, Digital Enlightenment Yearbook 2012, 57-75 (2012).

10. M. Bartling B. Resch, A. Eitzinger, L. Zurita-Arthos, A multi-national humancomputer interaction evaluation of the public participatory GIS GeoCitizen, GI_Forum 2019, 1, 18-39 (2019).

11. S. Hennig, R. Vogler, YouthMap 5020! What should youth-centred web maps look like?, GI_Forum 2014, 1, 285-294, (2014).

12. International perspectives on teaching and learning with GIS in secondary schools (Edited by A. Milson, A. Demirci, J. Kerski. New York: Springer, 2012).

13. Using geoinformation in European geography education (Edited by K. Donert. Rome: International Geographic Union, 2010).

14. I. Gryl, T. Jekel, Re-centring Geoinformation in Secondary Education: Toward a Spatial Citizenship Approach, Cartographica: The International Journal for Geographic Information and Geovisualization 47, 1, 18-28 (2012).

15. F.J. Fernandez-Cruz, M.J. Fernandez-Diaz, Teachers Generation $Z$ and their Digital Skills. Comunicar, 24, 46, 97-105 (2016).

16. P. Blumenfeld, E. Soloway, R.W. Marx, J.S. Krajcik, M. Guzdial, A. Palincsar, Motivating project-based learning: Sustaining the doing, supporting the learning, Educational Psychologist 26, 369-398 (1991).

17. F. Delattre "Mapping the Thien Sgan mountains" [Online]. Available: https://www.hotosm.org/updates/2016-05-10 mapping the tien shan mountains [Accessed June 28 2020].

18. Learning to Think Spatially (Edited by National Research Council. Washington, DC: The National Academies Press, 2006).

19. D. Stuart Sinton, S.W. Bednarz, P. Gersmehl, R.A. Kolvoord, D.H. Uttal, The People's Guide to Spatial Thinking, National Council for Geographic Education (2013).

20. J.B. Harley, Deconstructing the Map, Cartographica 26, 2, 1-20 (1989).

21. J.W. Crampton, Maps as Social Constructions: Power, Communication and Visualization, Progress in Human Geography 25, 2, 235-352 (2001)

22. J. Pickles, Ground Truth 1995-2005, Transactions in GIS 10, 5, 763-772 (2006)

23. B. Werlen, Society action and space: an alternative human geography (London \& New York: Routledge, 2006).

24. S. Elwood, K. Mitchell, Another Politics Is Possible: Neogeographies, Visual Spatial Tactics, and Political Formation, Cartographica: The International Journal for Geographic Information and Geovisualization 48, 4, 275-292 (2013).

25. W.L. Bennett, C. Wells, A. Rank, Young citizens and civic learning: two paradigms of citizenship in the digital age, Citizenship Studies 13, 2, 105-120 (2009).

26. R. Vogler, S. Hennig, T. Jekel, K. Donert (2012). Towards a concept of spatially enabled learning. In T. Jekel, A. Car, J. Strobl, \& G. Griesebner (Eds.), GI_Forum 2012: Geovizualisation, Society and Learning, 204-211. Berlin: Wichmann.

27. R. Vogler, T. Jekel, E. Killingseder, Using the Geographies of Learning. An Exploratory Categorization for Spatially Enabled Learning, GI_Forum 2018, 2, 181-192 (2018). 
28. A. Paivio, Mental Representations: A dual coding approach (New York: Oxford University Press, 1990).

29. D. Wood, The Power of Maps (London: Routledge, 1993).

30. R. Vogler, S. Hennig, M. Lindner-Fally, Shrinking technical Challenges - Zur strukturierten Erstellung digitaler Karten im Unterricht, GW-Unterricht 137, 1, 49-60 (2015).

31. B. Vockner, R. Vogler, C. Atzl, M. Mittlböck, THE4BEES - Energieverständnis durch smarte Gebäude, AGIT - Journal für Angewandte Geoinformatik, 2018, 4, 348-353 (2018).

32. S. Hennig, L. Abad, D. Hölbling, Geo citizen science and the role of participatory design in the field of geomorphology, InterCarto. InterGIS. GI support of sustainable development of territories: Proceedings of the International conference 26, 1, 116-126 (Moscow: Moscow University Press, 2020).

33. S. Hennig, R. Vogler, User-Centred Map Applications Through Participatory Design. Experiences Gained During the 'YouthMap 5020' Project, The Cartographic Journal 53, 3, 213-229 (2016).

34. N. De Luca, N. Ferber, H. Atteneder, T. Jekel, Feminist and Queer Approaches to Education for Spatial Citizenship, GI_Forum 2015, 1, 272-282 (2015).

35. J. Kerski, Geo-awareness, Geo-enablement, Geotechnologies, Citizen Science, and Storytelling: Geography on the World Stage, Geography Compass 9, 14-26 (2015).

36. D.Z. Sui, S. Elwood, M.F. Goodchild, Crowdsourcing Geographic Knowledge (Berlin: Springer, 2013).

37. L. Keller, A. Oberrauch, Can innovative learning settings support Education for Sustainable Development? - Teenagers from Northern and Southern Tyrol perform research on quality of life, Standards and Research in Geography Education. Current Trends and International Issues. (Edited by D. Schmeinck, \& J. Lidstone, J., Berlin: Mensch und Buch Verlag, 81-92, 2013).

38. R. Prüller, J. Scholz, C. Strauß, T. Achleitner, Teaching GIS in Central Asia, Vermessung \& Geoinformation 1, 174-178 (2009).

39. J. Lave, E. Wenger, Situated learning: Legitimate peripheral participation (Cambridge: Cambrige University Press, 1991).

40. T.D. Sadler, Situated learning in science education: socio-scientific issues as contexts for practice, Studies in Science Education 45, 1, 1-42 (2009).

41. E.G. Clary, M. Snyder, R.D. Ridgr, J. Copeland, A.A. Stukas, J. Haugen P. Miene, Understanding and assessing the motivations of volunteers: a functional approach, Journal of Personality and Social Psychology 74, 6, 1516-1530 (1998).

42. T.F. Dapp, The digital society. New ways to more transparency, participation and innovation (Frankfurt: Deutsche Bank Research, 2011).

43. A. Martin, Digital literacy and the "Digital Society", Digital Literacies: Concepts, Policies and Practices (Edited by C. Lankshear, M. Knobel, M. Peters, New York, Oxford: Peter Lang, 151-176, 2008).

44. S. Enemark, A. Rajabifard, Spatially Enabled Society, Geoforum Perspektiv Tidsskrift for Geografisk Information 20, 3-16 (2011).

45. A. Koller, T. Jekel, R. Vogler, RECC Geographie und Wirtschaftskunde-Geomedien, GW Unterricht 151, 2, 66-68 (2018).

46. NCVO Knowhow "How to engage with young people in your community" [Online]. Available: https://knowhow.ncvo.org.uk/how-to/how-to-engage-with-young-people-inyour-community\# [Accessed June 28 2020].

47. Worldbank "Uzbekistan Country Profil" [Online]. Available: https://databank.worldbank.org/views/reports/reportwidget.aspx?Report Name=Countr 
yProfile $\& \mathrm{Id}=\mathrm{b} 450 \mathrm{fd} 57 \& \mathrm{tbar}=\mathrm{y} \& \mathrm{dd}=\mathrm{y} \& \mathrm{inf}=\mathrm{n} \& \mathrm{zm}=\mathrm{n} \&$ country=UZB $[$ Accessed June 28 2020].

48. S. Hennig, A. Nazakulova, Benefits and challenges of eLearning in Central Asia, International Journal of Geoinformatics 15, 4, 43-51 (2019).

49. GPS Global Partership "Education Sector Plan (ESP) of Uzebekistan 2019-2023" [Online]. Available: https://www.globalpartnership.org/sites/default/files/2019-04-gpeesp-uzbekistan.pdf [Accessed June 28 2020].

50. O. Akbarov, B. Markus, A. Podor, Development of Advanced Education in Geoinformatics for Enabling Sustainable Development in Uzbekistan (Proceedings FIG Congress, 1-15, 2014). 